\title{
ETIOLOGY OF PARKINSONISM IN A BRAZILIAN MOVEMENT DISORDERS CLINIC
}

\author{
FRANCISCO CARDOSO*, SARAH T CAMARGOS**, GERALDO A SILVA JR ${ }^{* * *}$
}

\begin{abstract}
Objective: The aim of the present study is to investigate whether there are geographic differences in the etiology of parkinsonism (PA). Background: $72 \%$ of patients with PA evaluated at movement disorders clinics in the Northern Hemisphere are diagnosed with Parkinson's disease (PD). Data regarding other regions are not available. Methods: We reviewed the charts of all patients with PA seen at the Federal University of Minas Gerais Movement Disorders Clinic from July 1993 through October 1995. PA was diagnosed by the presence of at least two of the following: rest tremor, bradykinesia, rigidity, and postural instability. The different etiologies were diagnosed based on standard clinical criteria Results: During the period of the study, PA was recognized in 338 subjects. The following clinical diagnoses were made: PD (68.9\%), drug-induced PA (DIP) (13.3\%), vascular PA (4.7\%), Progressive supranuclear palsy (PSP) (2\%), multiple system atrophy (MSA) (1.8\%), others (9.7\%). Cinnarizine, haloperidol and flunarizine were the commonest drugs related to DIP. Conclusions: Similarly to other studies, PD accounts for about $70 \%$ of PA patients. However, there are differences between our results and previous series. DIP is much more common in the present series. This may be accounted for a more liberal use of antidopaminergic drugs in our environment, especially Calcium channel blockers. The lower frequency of MSA and PSP in our study may reflect a short follow-up, since many patients initially diagnosed with PD later are found to have Parkinson-plus syndromes.
\end{abstract}

KEY WORDS: parkinsonism, parkinsonian syndrome, epidemiology, parkinson's disease, drug-induced parkinsonism, vascular parkinsonism, progressive supranuclear palsy, multiple system atrophy, cinnarizine, flunarizine, calcium channel blockers.

\section{Etiologia de parkinsonismo em uma clínica brasileira de distúrbios do movimento}

RESUMO - Objetivo: O objetivo deste estudo é investigar se há diferenças geográficas na etiologia de parkinsonismo (PA). Panorama: $72 \%$ dos pacientes com PA avaliados em Clínicas de Distúrbios do Movimento no hemisfério norte são diagnosticados com doença de Parkinson (DP). Dados a respeito de outras regiões não se encontram disponíveis. Métodos: Nós revisamos os prontuários de todos pacientes com PA vistos na Clínica de Distúrbios de Movimentos da Universidade Federal de Minas Gerais entre Julho 1993 e outubro 1995. PA foi diagnosticado pela presença de no mínimo dois dos seguintes: tremor de repouso, bradicinesia, rigidez e instabilidade postural. As diferentes etiologias foram diagnosticadas baseadas em critérios clínicos padrões Resultados: Durante o período do estudo, PA foi reconhecido em 338 indivíduos. Os seguintes diagnósticos clinícos foram feitos: DP (68,9\%), PA induzido por droga (PID) (13,3\%), PA vascular (4,7\%), paralisia supranuclear progressiva (PSP) (2\%), atrofia de múltiplos sistemas (AMS) $(1,8 \%)$, outros $(9,7 \%)$. Cinarizina, haloperidol e flunarizina foram as drogas mais comumente relacionadas a PID. Conclusões: À semelhança de outros estudos, DP é responsável por cerca de 70\% dos casos de PA. Existem, porém, diferenças entre nossos resultados e outras séries. PID é muito mais comum na população estudada. Isso pode ser explicado por uso mais liberal de drogas antidopaminérgicas no nosso meio, sobretudo bloqueadores de canal de Calcio. A baixa frequência de AMS e PSP no nosso estudo pode refletir tempo de seguimento curto, já que muitos pacientes com diagnóstico inicial de DP posteriormente desenvolvem síndrome Parkinson-plus.

PALAVRAS-CHAVE: parkinsonismo, síndrome parkinsoniana, epidemiologia, doença de Parkinson, parkinsonismo induzido por droga, parkinsonismo vascular, paralisia supranuclear progressiva, atrofia de múltiplos sistemas, cinarizina, flunarizina, bloqueadores de canal de cálcio.

Movement Disorders Clinic, Department of Neurology, The Federal University of Minas Gerais, Belo Horizonte, MG, Brazil: *Associate Professor, **Medical Student, ***Resident. Aceite: 23-janeiro-1998.

Francisco Cardoso MD - Av Pasteur 89/1107 - 30150-290 Belo Horizonte MG - Brasil. FAX 55312366139. E-mail: cardosof@metalink.com.br 
Parkinsonism is defined as a combination of two or more of the following: tremor, rigidity, bradykinesia, postural reflex impairment, and motor blocks ${ }^{1}$. As all disorders associated with deficiency of dopamine in the striatum may lead to parkinsonism ${ }^{2}$, there is a long and growing list of causes of this syndrome ${ }^{3}$. In clinical studies, Parkinson's disease (PD) has been found to be the commonest cause of parkinsonian syndrome ${ }^{4}$. For instance, PD accounted for $77.7 \%$ of 2052 consecutive patients with parkinsonism seen at a Movement Disorder Clinic, whereas parkinsonism plus syndromes were diagnosed in $12.2 \%$ of patients ${ }^{5}$. Little is known, however, about geographic differences in the etiologic categories of parkinsonism.

The aim of the present study is to investigate the causes of parkinsonian syndrome at a movement disorders clinic in a developing country. By comparing our results with data available in the literature, we intend to determine whether etiology of parkinsonism varies in different geographic areas.

\section{PATIENTS AND METHODS}

We included in the present study all patients with parkinsonism evaluated at the Movement Disorders Clinic of the Federal University of Minas Gerais (MDC-UFMG) from July 1993 through October 1995. Parkinsonism was diagnosed if the patient displayed two or more of tremor, rigidity, bradykinesia, postural reflex impairment, and motor blocks ${ }^{1}$. PD was diagnosed according to the British Brain Bank Criteria ${ }^{6}$. The diagnostic criteria for progressive supranuclear palsy (PSP), multiple system atrophy (MSA), and other parkinsonism plus syndromes were published elsewhere ${ }^{7-9}$. Drug-induced parkinsonism (DIP) was diagnosed if the patient developed parkinsonian syndrome during the use of drug whose discontinuation was associated with improvement of parkinsonism without use of antiparkinsonian agents. We diagnosed vascular parkinsonism (VaP) if the patient met all the following criteria: symmetric parkinsonian syndrome; parkinsonism more severe in the lower half of the body, often associated with "frontal gait disorder" vascular lesions; patient does not fulfill criteria for previously mentioned conditions.

The evaluation included standard neurologic examination and assessment of parkinsonian symptoms and signs with the Unified Parkinson's Disease Rating Scale ${ }^{11}$. Dementia was diagnosed according to the DSM-IV criteia $^{12}$. One of us (FC) examined all patients. Data were entered into a relational database. Differences among studied parameters were analyzed by the $t$ test. Significant difference was considered at $p<0.05$.

\section{RESULTS}

Out of 1100 consecutive patients evaluated at the MDC-UFMG from Julho 1993 through Outubro 1995,338 subjects $(30.7 \%$ ) met the diagnostic criteria for parkinsonism. Table 1 contains demographic features of the studied population. The commonest etiologic category was PD, diagnosed in 233 patients (68.9\%), followed by DIP (13.3\%), VaP (4.7\%), PSP (2\%), and MSA (1.8\%). Subjects with VaP are significantly older than patients with PD and DIP at the onset of the parkinsonism (Table 1). Calcium channel blockers, cinnarizine and flunarizine are second only to haloperidol as the commonest agents responsible for DIP (Table 2). Less common causes of parkinsonism in our population are listed in Table 3. Table 4 shows the most important clinical features of the patients within the commonest etiologic categories. Bradykinesia, rigidity, gait disorder, postural instability and 1-dopa improvement are less

Table 1. Demographic features.

\begin{tabular}{ccccc}
\hline & Total & PD & DIP & VaP \\
\hline $\mathrm{N}$ & 338 & 233 & 45 & 16 \\
$\mathrm{M} / \mathrm{F}$ & 1.3 & 1.5 & 0.7 & 1.7 \\
Age at Onset (y) & $57.7 \pm 15.6$ & $58.1 \pm 12.3$ & $57.2 \pm 20.8$ & $69 \pm 9.8 \dagger+$ \\
Follow Up (w) & $10.9 \pm 21.3$ & $48.4 \pm 101.2$ & $38.8 \pm 60.8$ & $25.3 \pm 29.1$ \\
\hline
\end{tabular}

$\dagger \mathrm{p}<0.05$ in relation to $\mathrm{PD} ; \neq \mathrm{p}<0.05$ in relation to DIP 
Table 2. Agents responsible for drug induced parkinsonism.

\begin{tabular}{lc}
\hline Drug* & Number of Patients \\
\hline Haloperidol & 17 \\
Cinnarizine & 12 \\
Flunarizine & 8 \\
Chlorpromazine & 3 \\
Others & 10 \\
\hline
\end{tabular}

*Four patients used more than one drug.

common in subjects with DIP in comparison to PD patients. On the other hand, less tremor and responsiveness to 1-dopa as well as higher percentage of dementia distinguish VaP from DP.

As of November 11, 1997, 806 patients with parkinsonism have been evaluated at the MDCUFMG. Although we have not performed a formal analysis, the distribution of etiologic categories for these additional 468 patients is essentially the same as for the initial 338 subjects described in details in the present study.

\section{DISCUSSION}

Similarly to studies performed in the northern hemisphere ${ }^{5}$, we have shown that PD is the commonest cause of parkinsonism in patients evaluated in a hospital setting in Brazil. On the other hand, there are important differences between our results and other reported series of patients with parkinsonian syndrome. Before discussing the difference in the following paragraphs, it should be stressed that our study has methodological limitations. The first one study is lack of pathological confirmation of the diagnosis of different etiologic categories of parkinsonian syndrome. As shown by Hughes et $\mathrm{al}^{6}$, up to $26 \%$ of clinical diagnosis of PD are shown to be equivocal at autopsy. However, to minimize this bias all patients have been prospectively followed by one of us (FC) and, more importantly,

Table 3. Other causes of parkinsonism.

\begin{tabular}{ll}
\hline Cause & Number of Patients \\
\hline Wilson's disease & 5 \\
Alzheimer's disease & 4 \\
Normal pressure hydrocephalus & 4 \\
CBGD & 3 \\
Juvenile parkinsonism & 3 \\
ALS-parkinsonism & 2 \\
Hypoxic-ischemic lesion & 1 \\
Neuroacanthocythosis & 1 \\
Machado-Joseph disease & 1 \\
Niemann-Pick type C & 1 \\
\hline
\end{tabular}

CBDG, cortico-basal ganglioma degeneration,

ALS, amyotrophic lateral sclerosis. 


\begin{tabular}{ccccc}
\hline & Total & PD & DIP & VaP \\
\hline Tremor & $285(84.3)$ & $206(88.4)$ & $39(86.7)$ & $10(62.5) \dagger \ddagger$ \\
Bradykinesia & $324(95.8)$ & $229(98.3)$ & $39(86.7) \dagger$ & $16(100) \ddagger$ \\
Rigidity & $319(94.4)$ & $226(97)$ & $39(86.7) \dagger$ & $16(100) \ddagger$ \\
Gait disorder & $313(92.6)$ & $219(94)$ & $40(88.9) \dagger$ & $16(100) \ddagger$ \\
Postural instability & $262(77.5)$ & $188(80.7)$ & $26(57.8) \dagger$ & $15(93.7) \ddagger$ \\
L-dopa improvement* & $225(87.2)$ & $189(92.6)$ & $9(56.2) \dagger$ & $7(70) \dagger$ \\
Dementia & $60(17.7)$ & $26(11.2)$ & $7(15.5)$ & $7(43.7) \dagger$ \\
Tardive dyskinesia & $102(30.2)$ & $79(34)$ & $10(22.2)$ & $3(18.7)$ \\
\hline
\end{tabular}

Percentage between parentheses. *Percentage of patients tried on L-dopa. $\dagger \mathrm{p}<0.05$ in relation to PD, $\ddagger \mathrm{p}<0.05$ in relation to DIP.

all comparisons were made with studies employing a similar methodology. Furthermore, we are aware that studies performed at tertiary centers where less typical patients may be over-representated are not necessarily representative of the general population. Therefore, our investigation does not intend to be an epidemiologic survey of the etiology of parkinsonism in the Brazilian population. Nevertheless, we believe that our results cast light on peculiarities of the causes of parkinsonian syndrome in Brazil since we have compared our findings to similar studies undertaken elsewhere.

We diagnosed DIP in a relatively large number of patients $(13.3 \%)$. This finding contrasts, for instance, with just 3\% of 7564 patients with parkinsonism at Baylor College of Medicine or Columbia-Presbyterian Medical Center in the USA having been diagnosed with DIP ${ }^{13}$. The discrepancy may reflect liberal prescribing practices in Brazil. This conclusion is supported by the finding that about $10 \%$ of DIP patients were exposed to more than one offending agent. It can be speculated that an ascertainment bias accounts for the high proportion of DIP in our series since virtually all patients with movement disorders seen at the Federal University of Minas Gerais are referred to our clinic. In this regard, the cohort we studied is more similar to the general population than the patients investigated in other centres. However, a recent epidemiologic population-based study showed that just $5 \%$ of all parkinsonian patients in Europe have DIP $^{14}$. One may argue that the over-representation of DIP in our series in comparison to cohorts of the North America may reflect the fact that cinnarizine and flunarizine, the commonest offending agents in our study, are not approved in the United States. However, despite these drugs being widely available in Europe, the EUROPARKINSON study ${ }^{14}$ found a percentage of DIP smaller than our investigation. Overall, these findings strenghten the hypothesis that the etiology of parkinsonism in Brazil and in the northern hemisphere are truly different. Furthermore, our results also highlight the part played by drugs other than classic neuroleptics in the etiology of DIP. Indeed, similarly to our study, calcium channel blockers were found to be the second commonest drug responsible for DIP in a recent investigation ${ }^{15}$. Despite clinical similarities between PD and DIP, we found bradykinesia, rigidity, postural reflex impairment, and improvement with 1-dopa to be less common in the latter. Furthermore, unlike PD, DIP is more common among women. Like tardive dyskinesia, this may reflect gender-related differences in prescription practices ${ }^{16}$.

Surprisingly, VaP accounted for a relatively large number of patients in the present series. This finding may be artefactual, reflecting uncertainties in the diagnostic criteria of $\mathrm{VaP}^{17}$. One can speculate, however, that stroke is more common in Brazil than in the northern hemisphere, resulting 
in a large number of patients with VaP. This would be similar to eastern countries, such as Japan and Taiwan, where vascular dementia is the commonest form of dementia ${ }^{18}$. Unsatisfactory public health conditions, ethnic factors or both might underlie the presumed high rate of stroke in Brazil. However, further work is necessary to confirm this hypothesis.

The high percentage of secondary forms of parkinsonism, DIP and VAP partly explains the low frequency of parkinsonism plus in the studied population. It is likely, however, that the short follow up period prevented us from recognizing more patients with these disorders. This conclusion is supported by the finding that PSP and MSA are often clinically indistinguishable from PD at the onset $^{7,8}$. It is interesting to notice, however, that a report in abstract form, describing demographic features of 757 parkinsonian patients in other Brazilian movement disorder clinic, has also identified a similarly low percentage of "Parkinson-plus syndromes"19.

\section{REFERENCES}

1. Jankovic J. Parkinsonism. In Wyngaarden JB, Smith LH Jr, Bennett JC (eds). Cecil textbook of medicine. Philadelphia: Saunders, 1992: 2130-2133.

2. Brooks DJ. PET studies on the early and differential diagnosis of Parkinson's disease. Neurology 1993;43 (Suppl 6):S6-S16.

3. Cardoso F, Jankovic J. Basal ganglia and movement disorders. In Rolak L, (ed.) Neurology secrets. Philadelphia: Hanley \& Belfus, 1993: 127-162.

4. Marsden CD. Parkinson's disease. J Neurol Neurosurg Psychiatry 1994;57:672-681.

5. Jankovic J. The atypical parkinsonian syndromes. In Fahn S, Marsden CD, Jankovic J (eds.) 4th annual course: a comprehensive review of movement disorders for the clinical practitioner. New York: Columbia University, 1994:253-289.

6. Hughes AJ, Daniel SE, Kilford L, Lees AJ. Accuracy of clinical diagnosis of idiopathic Parkinson's disease: a clinicopathological study of 100 cases. J Neurol Neurosurg Psychiatry 1992;55:1009-1013.

7. Cardoso F, Jankovic J. Progressive supranuclear palsy. In Calne DB (ed.) Neurodegenerative diseases. Philadelphia: Saunders, 1994:769-786.

8. Quinn N. Multiple system atrophy. In Marsden CD, Fahn S, (eds.) Movement disorders - 3. Oxford: Butterworth-Heinemann, 1994:262-281.

9. Stacy M, Jankovic J. Differential diagnosis of Parkinson's disease and the Parkinsonism plus syndromes. Neurol Clin 1992;10:341-359.

10. Fitzgerald PM, Jankovic J. Lower body parkinsonism: evidence for vascular etiology. Mov Disord 1989;4:249-260.

11. Fahn S, Elton RL, Members of the UPDRS Development Comitee. Unified Parkinson's disease rating scale. In Fahn S, Marsden CD, Calne DB, Goldstein M, (eds.) Recent development in Parkinson's disease, Vol 2. Florham Park: McMillan Health Care Information, 1987:153-163.

12. Task Force on DSM-IV. Diagnostic and statistical manual of mental disorders. Ed. 4 Washington, DC: American Psychiatric Association, 1994.

13. Fahn S. Differential diagnosis of movement disorders. In Fahn S, Marsden CD, Jankovic J. (eds). 6th annual course: a comprehensive review of movement disorders for the clinical practitioner. New York: Columbia University, 1996: 3-58.

14. de Rijk MC, Tzourio C, Breteler MMB et al. Prevalence of parkinsonism and Parkinson's disease in Europe: the EUROPARKINSON collaborative study. J Neurol Neurosurg Psychiatry 1997;62:10-15.

15. Llau ME, Nguyen L, Senard JM et al. Syndromes parkinsoniens d'origine medicamenteuse: experience d'un centre regional de pharmacovigilance sur dix ans. Rev Neurol 1994;150:756-762.

16. Stacy M, Cardoso F, Jankovic J. Tardive stereotypies and other movement disorders in tardive dyskinesias. Neurology 1993;43:937-941.

17. Zijlmans JC, de Koster-A, van-'t-Hof MA et al. Proton magnetic resonance spectroscopy in suspected vascular ischemic parkinsonism. Acta Neurol Scand 1994;90:405-411.

18. Yoshitake T, Kiyohara Y, Kato Y et al. Incidence and risk factors of vascular dementia and Alzheimer's disease in a defined elderly population: the Hisayama study. Neurology 1995;45:1161-1168.

19. Lino AMM, Haddad MS, Carrilho PM et al. Parkinsonismo: caracterização de uma população de 757 casos. Arq Neuropsiquiatr 1992;50 (Supl):65. 